\title{
Sources of variation in milk urea nitrogen in Paraná dairy cows
}

\author{
Maria Cecília Doska ${ }^{1}$, Delma Fabíola Ferreira da Silva ${ }^{2}$, José Augusto Horst ${ }^{3}$, Altair Antônio \\ Valloto $^{3}$, Paulo Rossi Junior ${ }^{4}$, Rodrigo de Almeida ${ }^{4}$
}

\footnotetext{
1 Programa de Pós-Graduação em Ciências Veterinárias - UFPR/Curitiba. Scholar from CAPES.

${ }^{2}$ Curso de Zootecnia da Universidade Federal do Paraná - UFPR/Curitiba, PR. Scientific Initiation Scholar from UFPR/Fundação Araucária.

${ }^{3}$ Associação Paranaense dos Criadores de Bovinos da Raça Holandesa - APCBRH/Curitiba, PR.

${ }^{4}$ Departamento de Zootecnia da UFPR/Curitiba, PR.
}

\begin{abstract}
The present study was conducted to determine the relationship between milk urea nitrogen (MUN) and milk yield, fat and protein contents, breed and season effects, parity and days in milk in dairy cows from Paraná State, Brazil. A total of 127,428 test-days from 16,013 dairy cows belonging to 96 herds enrolled in an official milk recording program were analyzed. Multivariate mixed model methodology was used to determine the relationship between MUN and the fixed effects and the covariable milk production. Milk urea nitrogen averaged $14.45 \pm 4.60 \mathrm{mg} / \mathrm{dL}$. Positive and intermediate association between MUN and milk yield $(r=0.34)$ were found. Holstein cows showed lower MUN adjusted means than crossbred, Jersey, and Brown Swiss cows: 14.18 vs. 15.49, 16.12, and $17.62 \mathrm{mg} / \mathrm{dL}$, respectively. First-lactation cows showed higher MUN values than second-lactation and older cows: 16.16 vs. 15.95, and $15.45 \mathrm{mg} / \mathrm{dL}$, respectively. MUN test-days collected during the winter were higher than those collected in the other seasons. The effects of the lactation stage on MUN were significant, with the highest MUN values observed in the sixth month of lactation. High-producing dairy cows showed higher milk urea concentrations but several environmental factors may contribute to reduce this important parameter of diet utilization efficiency.
\end{abstract}

Key Words: dairy cattle, nutrition, protein

\section{Introduction}

As a result of environmental and genetic improvements and the development and implementation of new technologies in the dairy industry, currently dairy cows produce larger amounts of milk and its components. In order to meet the nutritional requirements of higher-producing cows, it is essential to use more elaborated diets. During lactation, the dietary demand for nitrogen compounds $(\mathrm{N})$ is critical because the secretion of milk proteins is higher, thus increasing blood urea concentrations and consequently milk urea concentrations. Milk urea nitrogen (MUN) has been used as an indicator to monitor the protein-energy balance of lactating cows (Jonker et al., 1999; Godden et al., 2001b), once it shows a high correlation with plasma and blood urea nitrogen (Roseler et al., 1993; Lucci et al., 2006). The samples to determine MUN were collected using a noninvasive and direct method through milk samples collected during milking, thus representing a simple, fast and cheap indicator to investigate the nutritional condition of lactating cows (Roseler et al., 1993; Butler et al., 1995).

Normal MUN values range from 10 to $14 \mathrm{mg} / \mathrm{dL}$ (Jonker et al., 1998; Johnson \& Young, 2003; Rajala-Schultz \&
Saville, 2003). These concentrations can vary from one herd to another, between groups of cows, and between cows of the same herd. Monitoring MUN monthly can be an important tool for dairy cattle management, and since protein supplements are expensive, the overconsumption of $\mathrm{N}$ can affect reproductive efficiency, and the excess of $\mathrm{N}$ excretion has a negative environmental impact (Ferguson et al., 1988; Rajala-Schultz \& Saville, 2003).

Although diet composition - especially crude protein (CP), rumen degradable and undegradable proteins (RDP and RUP) and nonstructural carbohydrates (NSC) - and feeding practices adopted in herds influence MUN concentrations (Godden et al., 2001b), other factors can change these values (Carlsson et al., 1995). Based on studies with dairy herds enrolled in a monthly milk recording program (Godden et al., 2001a,b; Arunvipas et al., 2003; Johnson \& Young, 2003; Rajala-Schultz \& Saville, 2003; Wattiaux et al., 2005), it was found that several non-nutritional factors are associated with MUN concentrations.

The objective of this study was to determine the relationship between MUN levels and non-nutritional factors such as milk yield, fat and protein contents, breed and season effects, parity and days in milk in dairy cows from 
the Paraná State, enrolled in an official milk recording program.

\section{Material and Methods}

A total of 127,428 test-days from 16,013 dairy cows enrolled in the PARLPR -Programa de Análise de Rebanhos Leiteiros do Paraná (Dairy Herd Analysis Program from Paraná State) of the APCBRH - Associação Paranaense de Criadores de Bovinos da Raça Holandesa were analyzed. The dairy cows were from 96 herds, distributed over 11 regions of Paraná State: Arapoti, Carambeí, Castro, CentroOeste, Curitiba, Noroeste, Norte, Oeste, Sudoeste, Sul and Witmarsum.

The original database analyzed had a total of 155,630 test-days collected between January/2007 and May/2010. In the edition of the database, the test-days from animals whose calving date was not registered and from herds outside Paraná State and from non-dairy or nontraditional breeds were discarded. Only the test-days from Holstein, Jersey, Brown Swiss, Crossbreds and Girolando genetic groups were kept. Girolando and crossbred cows were merged in a single group called "Crossbreds". Test-days from cows with days in milk above 1,905 days (3 years), test-days with negative age, and with age at calving below 18 months or above 150 months were removed as well. Testdays without production data, production lower than 1 liter/ cow/day, fat percentages $<1 \%$ and $>9 \%$, protein percentages $<1 \%$ and $>7 \%$, somatic cell count (SCC) equal to zero and test-days with MUN values $<1 \mathrm{mg} / \mathrm{dL}$ or $>50 \mathrm{mg} / \mathrm{dL}$ were also eliminated. A MUN frequency distribution was designed to determine whether values followed a normal distribution. Herds with four or fewer test-day months during the study period, and herds with less than 100 testdays over the entire period analyzed were also rejected.

The equipment used to determine MUN was the Bentley Instruments ${ }^{\circledR}$ ChemSpec 150 from the PARLPR laboratory Laboratório Centralizado de Análise de Leite - located in Curitiba, Paraná State. This automated equipment can analyze up to 150 samples of MUN per hour, through an enzymatic and spectrophotometry in a trans-reflectance cell methodology.

The descriptive data analysis was performed for herds, region, breed, lactation number, season of the year, milking frequency and days in milk through PROC FREQ of SAS (Statistical Analysis System, version 9.0). Pearson correlations between MUN, milk yield and the main milk components were estimated using PROC CORR of SAS. The significance of region, breed, lactation number, season, days in milk (15 categories of 30 days in milk each) and milking frequency fixed effects in MUN were determined by SAS MIXED procedure (Statistical Analysis System, version 9.0) using a multiple linear regression model. The linear effect of milk yield was estimated by the REG procedure of SAS (Statistical Analysis System, version 9.0) and included in the statistic model as covariable. Herd nested in the region was included in the model as a random effect. As Wattiaux et al. (2005), in his study with 400,729 MUN test-days in the Midwestern United States, it was not possible to include the cow random effect in the model because computational resources were insufficient. Differences between the adjusted means were determined by the TukeyKramer test, with $1 \%$ probability.

\section{Results and Discussion}

The average concentration of milk urea nitrogen was $14.45 \pm 4.60 \mathrm{mg} / \mathrm{dL}$ (Table 1), a value slightly above the maximum limit suggested for this parameter (between 10 and $14 \mathrm{mg} / \mathrm{dL}$ ), and consistent with several review studies (Jonker \& Kohn, 1998; Jonker et al., 1998; Rajala-Schultz \& Saville, 2003; Johnson \& Young, 2003; Meyer et al., 2006; Cordeiro et al., 2007).

Many studies have reported that both high (Payne \& Payne, 1987; Jonker et al., 1998; Godden et al., 2001b) and low (Roseler et al., 1993; Godden et al., 2001b) MUN concentrations may indicate problems in dairy cattle herds. High MUN values may be a sign of excessive rumen degradable protein (RDP) and/or rumen undegradable protein (RUP) in the diet, low rumen fermentation rate of non-fiber carbohydrates (NFC) or increased CP:NSC ratio. Low values of MUN may be a sign of CP deficiency in the diet, limited dietary amounts of RDP and RUP or high NSC fermentation rate in the rumen (Godden et al., 2001b).

Payne \& Payne (1987), Roseler et al. (1993), Jonker et al. (1998) and Pina et al. (2006) recognized the importance of

Table 1 - Descriptive analysis of the variables studied

\begin{tabular}{lc}
\hline Variable & Mean \pm SD \\
\hline Age at calving (months) & $45.8 \pm 21.8$ \\
DIM & $204.9 \pm 141.3$ \\
Milk yield (kg/day) & $32.4 \pm 11.5$ \\
MUN (mg/dL) & $14.45 \pm 4.60$ \\
Fat (\%) & $3.40 \pm 0.73$ \\
Protein (\%) & $3.13 \pm 0.35$ \\
Lactose (\%) & $4.54 \pm 0.28$ \\
Total solids (\%) & $12.00 \pm 0.99$ \\
SCC x 1000 & $383 \pm 817$ \\
\hline
\end{tabular}

SD - standard deviation; DIM - days in milk; MUN - milk urea nitrogen; SCC - somatic cell count. 
energy and protein balance to prevent the body from excreting large amounts of nitrogen. Oltner \& Wiktorsson (1983) and Hoffman \& Steinhöfel (1990) showed that variations in protein intake did not affect MUN when the protein-energy ratio was preserved.

Animals have an average daily milk yield of $32.4 \pm 11.5 \mathrm{~kg} /$ day and fat and protein percentages of $3.40 \pm 0.73 \%$ and $3.13 \pm 0.35 \%$, respectively. These results are similar to those found by Rajala-Schultz \& Saville (2003) and Meyer et al. (2006). The general means for age at calving and days in milk were $45.8 \pm 21.8$ months and $205 \pm 141$ days, respectively. It is important to point out that the animals included in this database were young, mostly Holsteins and with a high milk production and correct milk composition. This shows that milk urea analysis is more frequently performed in high-producing herds, since it is collected in a voluntary basis and represents an extra cost in the monthly milk recording. In fact, in 2010, the APCBRH kept in official milk recording program 1,274 herds with an average milk production of $27.3 \mathrm{~kg} /$ day, $5 \mathrm{~kg} /$ day less than the average milk production of the database analyzed in the present study (APCBRH, 2011).

The linear correlation between MUN and milk yield was moderate and positive $(\mathrm{r}=0.34 ; \mathrm{P}<0.01)$, similarly to the results found by Joknker et al. (1998) and Meyer et al. (2006), confirming that higher-producing groups and herds can present higher MUN values. Therefore, the milk production covariable was included in the model, being an important source of variation $(\mathrm{P}<0.01)$ in milk urea.

As recommended by the NRC (2001), cows fed according to the lactation stage have their milk production increased; however, the amount of crude protein consumed also goes up. Supplementary protein can improve milk production by providing more amino acids for milk protein synthesis, increasing the energy available through amino acid deamination or changing the utilization efficiency of the absorbed nutrients by the body (Chalupa, 1984). Consequently, high protein levels in the diet cause more ammonia to be available in the rumen, which can increase MUN concentrations (Jonker et al., 1998). Godden et al. (2001a) observed a high positive but non-linear correlation between MUN and milk production and suggested that this result would be due to the use of diets rich in protein for high-production cows. According to Meyer et al. (2006), a possible explanation for the increase in MUN concentrations, regarding the increase in milk production, might be the fact that the most limiting nutrient for high-production cows is energy. Therefore, in order to obtain the required energy intake, the animal would increase the dry matter (DM) intake, thus consuming protein in excess when compared with energy.

On the other hand, Gustafsson \& Carlsson (1993) and Eicher et al. (1999) did not find any correlations between urea and milk production, whereas Trevaskis \& Fulkerson (1999) observed that milk production in pasture-raised cows was negatively associated to milk urea concentration.

The correlations between MUN and fat and protein contents were negative and of lower magnitude $(r=-0.11$; $\mathrm{P}<0.01$ ), consistent with the reports of Godden et al. (2001a) and Johnson \& Young (2003). Johnson \& Young (2003) found that the higher the milk protein content, the smaller the MUN values. This pattern was also observed by the same authors for milk fat percentage but to a lesser extent. Carlsson \& Bergström (1994) reported that an increase in milk fat percentage can have a negative effect in MUN concentration, whereas Meyer et al. (2006) found a positive correlation between MUN and the major milk components. In the present study, the phenotypic correlations between MUN and lactose content, total solids content and somatic cell count were $+0.16,-0.07$ and -0.13 , respectively.

All the fixed effects included in the statistical model influenced MUN $(\mathrm{P}<0.01)$. MUN adjusted mean for Holsteins was lower $(\mathrm{P}<0.01)$ than those of crossbreds, Jerseys and Brown Swiss cows: 14.18; 15.49; 16.12 and $17.62 \mathrm{mg} / \mathrm{dL}$, respectively (Figure 1). These results contrast with those found by Johnson \& Young (2003). They observed higher MUN values for Holsteins (15.5 mg/dL) and lower values for Jersey cows $(14.1 \mathrm{mg} / \mathrm{dL})$.

On the other hand, Jonker et al. (1998) reported that body weight is negatively correlated with MUN in dairy cows, consistent with the results found in the present study. There was no certainty for what caused the differences in MUN values among the different genetic

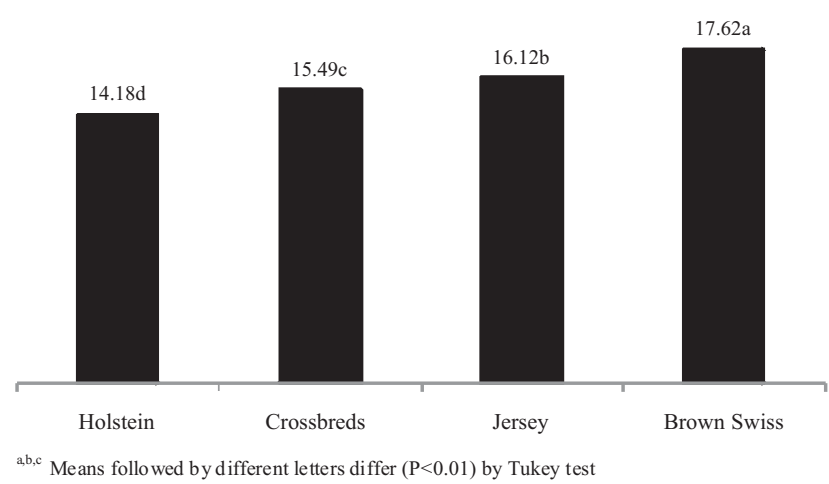

Figure 1 - Average test-day milk urea nitrogen concentrations (mg/dL) for different genetic groups. 
groups, but it is important to point out that $94.9 \%$ of the testdays analyzed in this study are from Holsteins, and that cows from other breeds are minority within Holstein herds. In other words, there are very few herds exclusively composed of non-Holstein cows on the available database. Thus, one can hypothesize that the diets in these herds were formulated according to the milk yield and composition of the dominant breed. Consequently, Holsteins would have a greater nitrogen utilization efficiency, which could lead to lower MUN concentrations.

First-lactation cows showed higher $(\mathrm{P}<0.01)$ MUN values than those of second-lactation and older cows: 16.16; 15.95 and $15.45 \mathrm{mg} / \mathrm{dL}$, respectively (Figure 2). This result is similar to those presented by Jonker et al. (1998), but contrasts with those found by Oltner et al. (1985), Ferguson (1999), Arunvipas et al. (2003) and Johnson \& Young (2003). They reported lower MUN values in firstlactation cows and ascribe this to the faster metabolism of these animals and consequently, greater amino acid utilization efficiency and lower conversion to urea. This can also be explained simply by the lower milk production of first-lactation cows.

The higher MUN values for younger cows found in this study may indicate an excess of dietary crude protein, since first-lactation cows in many dairy herds in Paraná State, although less productive, are fed the same diet of adult high-producing cows.

Concentrations of milk urea nitrogen were higher $(\mathrm{P}<0.01)$ during the winter $(16.24 \mathrm{mg} / \mathrm{dL})$, intermediate during the spring $(15.88 \mathrm{mg} / \mathrm{dL})$ and lower during the fall and summer (15.69 and $15.60 \mathrm{mg} / \mathrm{dL}$, respectively) (Figure 3). These results are opposite to those found by Carlsson et al. (1995), Godden et al. (2001), Arunvipas et al. (2002) and Rajala-Schultz \& Saville (2003). They observed higher MUN values during the hottest seasons of the year.

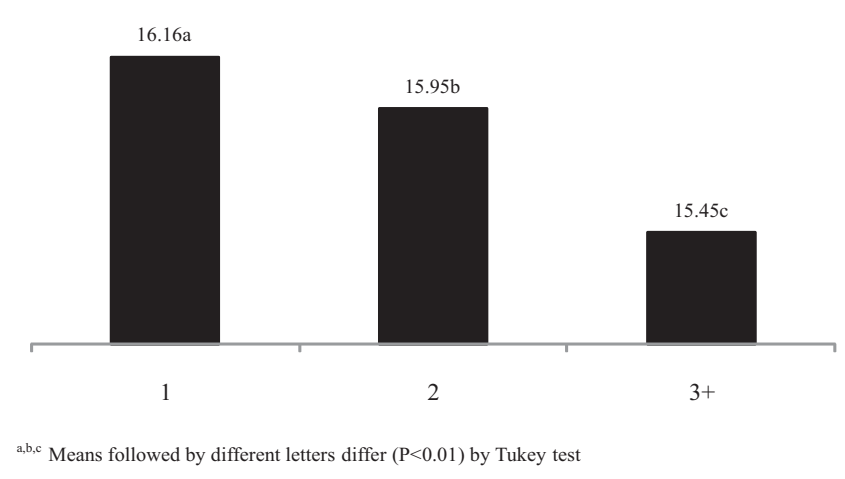

Figure 2 - Average test-day milk urea nitrogen concentrations (mg/dL) for different parity groups.
Moller et al. (1993) stated that the variation in MUN was due to the seasonal variations in pasture protein and energy components. Spring pasture is rich in protein (more than $20 \%$ of $\mathrm{CP}$ ) and poor in soluble carbohydrates, thus creating an increased protein-energy ratio, which can result in high MUN concentrations. In the present study, increased MUN concentrations during the winter are probably due to the greater availability of winter grasses rich in protein, common at this time of the year in Brazil and especially in the Campos Gerais region, Paraná State, the main origin of the database analyzed.

The variation in MUN values according to the lactation stage is similar to the typical shape of a lactation curve (Figure 4). However, in the present study, MUN concentrations peaked between 151 and 180 days in milk (16.35 mg/dL), whereas milk production peaked around 45-60 days (NRC, 2001). Carlsson et al. (1995), Trevaskis \& Fulkerson (1999) and Rajala-Schultz \& Saville (2003) reported similar patterns. The reason MUN had its peak around the middle of the lactation period is probably due to the higher consumption of dry matter and consequently of crude protein during this stage of lactation.

Godden et al. (2001a) reported a positive but non-linear correlation between milk urea and days in milk and observed that MUN concentrations were lower in the first 60 days, increased between 60 and 150 and decreased after 150 days in lactation. According to Godden et al. (2001a), differences in DM intake, rumen microbial adaptation and the absorptive capacity may have caused the differences in milk urea during the different stages of lactation. Arunvipas et al. (2002) associated the lowest MUN level during the first month of lactation (10.14 $\mathrm{mg} / \mathrm{dL})$ explained by the low DM intake during this period. MUN reached its peak at the fourth month of lactation $(11.80 \mathrm{mg} / \mathrm{dL})$ due to the increase in DM intake, and decreased at the end of lactation $(10.56 \mathrm{mg} / \mathrm{dL})$ as

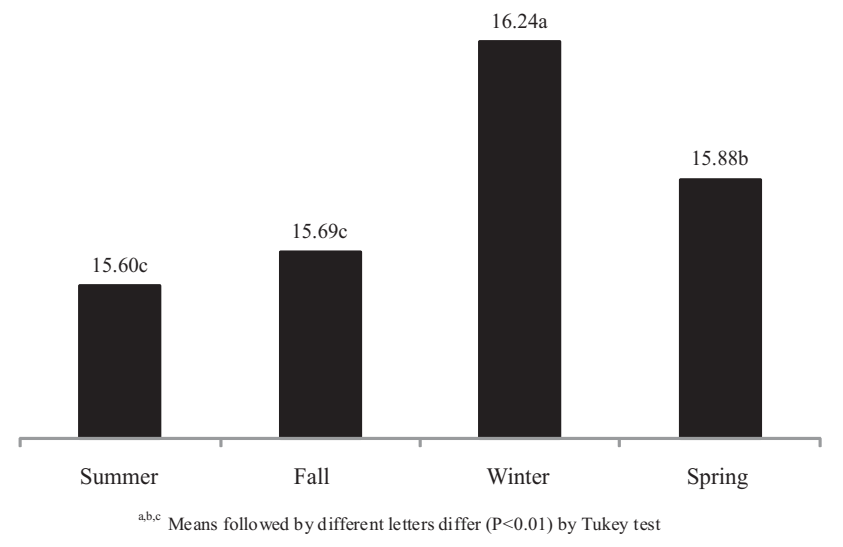

Figure 3 - Average test-day milk urea nitrogen concentrations $(\mathrm{mg} / \mathrm{dL})$ for different seasons of the year. 


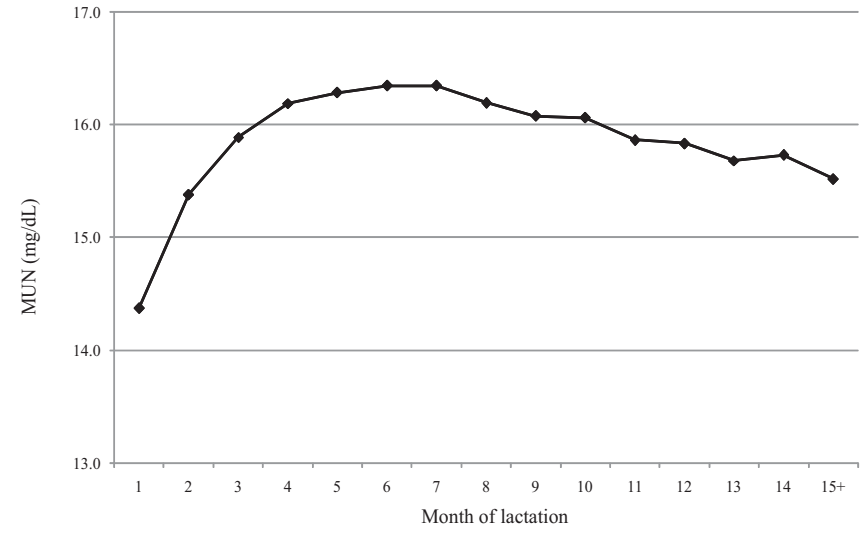

Figure 4 - Relationship between milk urea nitrogen (MUN) concentrations (mg/dL) and month of lactation.

a result of the reduction in DM and protein consumption in this stage. Lucci et al. (2006) found that the concentrations of plasma and milk urea nitrogen increased throughout the weeks after calving, which was attributed to the higher CP content of the feed consumed as soon as they started the lactation period.

Cows milked more frequently (3 times/day) had higher $(\mathrm{P}<0.01)$ MUN concentrations $(16.40 \mathrm{mg} / \mathrm{dL})$ than cows milked twice a day $(15.31 \mathrm{mg} / \mathrm{dL})$. According to Jonker et al. (1998), this is probably caused by the higher intake of crude protein by higher-producing cows.

\section{Conclusions}

Milk urea nitrogen concentrations are positively associated with milk production. Several effects seem to affect milk urea nitrogen, especially the effects of season (higher milk urea nitrogen values during winter), breed (lower values for Holsteins cows), parity (higher values for younger cows) and days in milk (higher values at the sixth month of lactation).

\section{References}

ASSOCIAÇÃO PARANAENSE DE CRIADORES DE BOVINOS DA RAÇA HOLANDESA - APCBRH. [2011]. Relatório Anual 2010 APCBRH. In: Boletim Informativo Associação Paranaense de Criadores de Bovinos da Raça Holandesa, Março, n.4, 2011. p.31. Available at: <http://www.holandesparana.com.br/ reAnual2010.html>. Accessed on: June 29, 2011.

ARUNVIPAS, P.; DOHOO, I.; VANLEEUWEN, J. et al. The effect of non-nutritional factors on milk urea nitrogen levels in Ayrshire dairy cows. Journal of Dairy Science, v.85, suppl.1, p.320, 2002.

ARUNVIPAS, P.; DOHOO, I.R.; VANLEEUWEN, J.A. et al. The effect of non-nutritional factors on milk urea nitrogen levels in dairy cows in Prince Edward Island, Canada. Preventive Veterinary Medicine, v.59, p.83-93, 2003.
BUTLER, W.R.; CHERNEY, D.J.R.; ELROD, C.C. Milk urea nitrogen: Field trial results on conception rates and dietary inputs. In: THE CORNELL NUTRITION CONFERENCE FOR FEED MANUFACTURES, 1995, Ithaca. Proceedings... Ithaca: Cornell University Press, 1995. p.89-94.

CARLSSON, J., BERGSTRÖM, J. The diurnal variation of urea in cow's milk and how milk fat content, storage and preservation affects analysis by a flow injection technique. Acta Veterinaria Scandinavica, v.35(1), p.67-77, 1994.

CARLSSON, J.; BERGSTROÖM, J.; PEHRSON, B. Variations with breed, age, season, yield, stage of lactation and herd in the concentration of urea in bulk milk and individual cow's milk. Acta Veterinaria Scandinavica, v.36, p.245-254, 1995.

CHALUPA, W. Discussion of protein symposium. Journal of Dairy Science, v.71, p.3470-3481, 1984.

CORDEIRO, C.F.A.; PEREIRA, M.L.A.; MENDONÇA, S.S. et al. Consumo e digestibilidade total dos nutrientes e produção e composição do leite de vacas alimentadas com teores crescentes de proteína bruta na dieta contendo cana-de-açúcar e concentrados. Revista Brasileira de Zootecnia, v.36, p.2118-2126, 2007 (supl.).

EICHER, R.; BOUCHARD, E.; TREMBLAY, A. Cow level sampling factors affecting analysis and interpretation of milk urea concentrations in 2 dairy herds. Canadian Veterinary Journal, v.40, p.487-492, 1999.

FERGUSON, J.D.; BLANCHARD, T.; GALLIGAN, D.T. et al Infertility in dairy cattle fed a high percentage of protein degradable in the rumen. Journal of the American Veterinary Medical Association, v.192, p.659-662, 1988.

FERGUSON, J.D. [1999]. Milk urea nitrogen. In: FERGUSON, J.D. (Ed.), June 29, 1999, p.1-6. Available at: <http:// cahpwww.nbc.upenn.edu/mun/muninfo.html> Accessed on: May 10, 2010.

GODDEN, S.M.; LISSEMORE, K.D.; KELTON, D.F. et al. Factors associated with milk urea concentrations in Ontario dairy cows. Journal of Dairy Science, v.84, p.107-114, 2001a.

GODDEN, S.M.; LISSEMORE, K.D.; KELTON, D.F. et al. Relationships between milk urea concentrations and nutritional management, production, and economic variables in Ontario dairy herds. Journal of Dairy Science, v.84, p.1128-1139, 2001b.

GUSTAFSSON, A.H.; CARLSSON, J. Effects of silage quality, protein evaluation systems and milk urea content on milk yield and reproduction in dairy cows. Livestock Production Science, v.37, p.91-105, 1993.

HOFFMANN, V.M.; STEINHÖFEL, O. Possibilities and limitations for appraisal of energy and protein supply through monitoring of mil urea level. Monatshefte für Veterinärmedizin, v.45, p.223-227, 1990.

JOHNSON, R.G.; YOUNG, A.J. The association between milk urea nitrogen and DHI production variables in Western commercial dairy herds. Journal of Dairy Science, v.86, p.3008-3015, 2003.

JONKER, J.S.; KOHN, R.A. MUN: testing: useful but ambiguous. Hoard's Dairyman, v.143, n.6, p.252, 1998.

JONKER, J.S.; KOHN, R.A.; ERDMAN, R.A. Using milk urea nitrogen to predict nitrogen excretion and utilization efficiency in lactating dairy cows. Journal of Dairy Science, v.81, p.2681-2692, 1998.

JONKER, J.S.; KOHN, R.A.; ERDMAN, R.A. Milk urea nitrogen target concentrations for lactating dairy cows fed according to National Research Council recommendations. Journal of Dairy Science, v.82, p.1261-1273, 1999.

LUCCI, C.S.; VALVASORI, E.; PEIXOTO JUNIOR, K. et al. Concentrações de nitrogênio na dieta, no sangue e no leite de vacas lactantes no período pós-parto. Revista Brasileira de Zootecnia, v.35, p.258-263, 2006.

MEYER, P.M.; MACHADO, P.F.; COLDEBELLA, A. et al. Fatores não-nutricionais e concentração de nitrogênio uréico no leite de vacas da raça Holandesa. Revista Brasileira de Zootecnia, v.35, p.1114-1121, 2006 (supl.). 
MOLLER, S.; MATTHEW, C.; WILSON, G.F. Pasture protein and soluble carbohydrate levels in spring dairy pasture and association with cow performance. Proceedings of the New Zealand Society of Animal Production, v.54, p.83-86, 1993.

NATIONAL RESEARCH COUNCIL - NRC. Nutrient requirements of dairy cattle. 7.rev. ed. Washington, DC: National Academy Press, 2001. 381p.

OLTNER, R.; WIKTORSSON, H. Urea concentrations of milk and blood as influenced by feeding varying amounts of protein and energy to dairy cows. Livestock Production Science, v.10, p.457-467, 1983.

OLTNER, R.; EMANUELSON, M.; WIKTORSSON, H. Urea concentrations in milk in relation to milk yield, live weight, lactation number and amount and composition of feed given to dairy cows. Livestock Production Science, v.12, p.47-57, 1985.

PAYNE, J.A.; PAYNE, S. The metabolic profile test. New York: Oxford University Press, 1987. 179p.

PINA, D.S.; VALADARES FILHO, S.C.; VALADARES, R.F.D. et al. Síntese de proteína microbiana e concentrações de uréia em vacas alimentadas com diferentes fontes de proteína. Revista Brasileira de Zootecnia, v.35, p.1552-1559, 2006.

RAJALA-SCHULTZ, P.J.; SAVILLE, W.J.A. Sources of variation in milk urea nitrogen in Ohio dairy herds. Journal of Dairy Science, v.86, p.1653-1661, 2003.

ROSELER, D.K.; FERGUSON, J.D.; SNIFFEN, C.J. et al. Dietary protein degradability effects on plasma and milk urea nitrogen and milk nonprotein nitrogen in Holstein cows. Journal of Dairy Science, v.76, p.525-534, 1993.

TREVASKIS, L.M.; FULKERSON, W.J. The relationship between various animal and management factors and milk urea, and its association with reproductive performance of dairy cows grazing pasture. Livestock Production Science, v.57, p.255-265, 1999.

WATTIAUX, M.A.; NORDHEIM, E.V.; CRUMP, P. Statistical evaluation of factors and interactions affecting dairy herd improvement milk urea nitrogen in commercial Midwest dairy herds. Journal of Dairy Science, v.88, p.3020-3035, 2005. 